\title{
POSTACIE KOBIECE STAREGO TESTAMENTU W ALEGORYCZNEJ EGZEGEZIE ORYGENESA
}

Najwybitniejszy wczesnochrześcijański przedstawiciel alegorycznej egzegezy biblijnej, Orygenes z Aleksandrii (185-253/254), był zwolennikiem radykalnego poglądu o wyrazowym natchnieniu Pisma Świętego, obejmującym każde słowo Biblii ${ }^{1}$, co w rezultacie prowadziło go do przekonania, że cały tekst Pisma wraz z najdrobniejszymi szczegółami zawiera sens duchowy, przeznaczony dla doskonałych, czyli duchowo dojrzałych chrześcijan ${ }^{2}$. Aleksandryjczyk interpretował alegorycznie, czyli przenośnie, wszelkie osoby, rzeczy i wydarzenia ze Starego Testamentu, stanowiące - według niego - typy rzeczywistości nowotestamentalnej ${ }^{3}$. Jednym z programowych tekstów biblijnych, wytyczających drogę postępowania Orygenesa, był fragment listu św. Pawła do Galatów (Ga 4, 22-24), w którym sam Apostoł pisał o konieczności alegorycznego rozumienia dwóch żon Abrahama - Hagar i Sary - jako typów Synagogi i Kościoła:

„W innym miejscu Apostoł mówi: «Abraham miał dwóch synów, jednego $\mathrm{z}$ niewolnicy, a drugiego z wolnej» $(\mathrm{Ga} 4,22)$. [...] Apostoł jednak dodaje: «To zaś ma sens alegoryczny» $(\mathrm{Ga} 4,24)$; zapis ten odnosi się do dwóch Testamentów i stwierdza, że potomstwo Sary, rodzącej ku wolności, oznacza

${ }^{*}$ Ks. prof. dr hab. Mariusz Szram - profesor zwyczajny w Katedrze Patrologii Greckiej i Łacińskiej w Instytucie Historii Kościoła i Patrologii na Wydziale Teologii Katolickiego Uniwersytetu Lubelskiego Jana Pawła II; e-mail: m.szram@wp.pl.

${ }^{1}$ Por. A. Zöllig, Die Inspirationslehre des Origenes. Ein Beitrag zur Dogmengeschichte, Freiburg-im-Breisgau 1902, passim; R.P.C. Hanson, Allegory and Event: A Study of the Sources and Significance of Origen's Interpretation of Scripture, London 1959, 187-199; E. Stanula, Teologiczne zasady interpretacji Pisma świętego, w: Orygenes, O zasadach, tłum. S. Kalinkowski, PSP 23, Warszawa $1979,38-41$.

${ }^{2}$ Por. H. de Lubac, Histoire et esprit. L'intelligence de l'Écriture d'après Origène, Paris 1950, passim; A.D. Papanikolau, The allegorical exegetical method of Origen, „Theologia” 45 (1974) 347-359; M. Harl, Origène et les interprétations patristiques grecques de l',obscurité” biblique, VigCh 36 (1982) 334-371; H. Crouzel, Orygenes, tłum. J. Margański, Bydgoszcz 1996, 99-128; J. Zieliński, Alegoreza jako metoda filozoficzno-egzegetyczna w ujęciu Orygenesa, „Acta Universitatis Wratislaviensis" 36 (1999) 295-320; M. Szram, Duchowy sens liczb w alegorycznej egzegezie aleksandryjskiej (II-V w.), Lublin 2001, 299-306.

${ }^{3}$ Por. H. de Lubac, ,, Typologie” et ,, allégorisme”, RechSR 34 (1947) 220-221: ,l'allégorisme d'Origène est avant tout «typologique»". 
synów Nowego Testamentu, natomiast potomstwo Hagar, rodzącej ku niewoli, nazywa dziećmi ziemskiej Jerozolimy"4.

Dalsza, nieuchronną konsekwencją egzegezy typologiczno-chrystologicznej było dla aleksandryjskiego teologa odnalezienie sensu moralno-mistycznego, dotyczącego relacji duszy ludzkiej do Boga. Podstawowy kierunek egzegezy biblijnej miała bowiem wytyczać ỏ $\varphi \hat{\lambda} \lambda \varepsilon \imath \alpha$, czyli korzyść duchowa odbiorcy ${ }^{5}$.

Orygenes poddawał alegoryzacji różne postacie starotestamentalne, zwłaszcza te, które miały hebrajskie imiona mówiące, dające duże możliwości skojarzeń z osobą i życiem Chrystusa i Kościoła, a przede wszystkim z duchowością człowieka. Znacząca grupę takich osób stanowiły kobiety. Aleksandryjczyk reprezentował w odniesieniu do płci żeńskiej podejście antropologiczne charakterystyczne dla kultury antycznej, zgodnie z którym kobieta symbolizowała to, co cielesne i zmysłowe, a mężczyzna to, co duchowe i rozumne ${ }^{6}$. Przykładem egzegezy alegorycznej dokonanej w tym duchu może być Orygenesowska interpretacja nakazu faraona uśmiercania hebrajskich noworodków płci męskiej, a pozostawienia przy życiu tylko dziewczynek (por. Wj 1, 15-22). Według Aleksandryjczyka nakaz ten miał oznaczać nienawiść Egipcjan do tego, co męskie, czyli do cnót, a oddawanie się temu, co żeńskie, czyli występkom i przyjemnościom ${ }^{7}$.

Orygenesowska egzegeza alegoryczna starotestamentalnych postaci kobiecych jest jednak wielopłaszczyznowa i odbiega od powyższego schematu, który mógł być powodem do oskarżania teologów i ascetów epoki patrystycznej

${ }^{4}$ Origenes, In Numeros hom. 11, 1, ed. L. Doutreleau, SCh 442, Paris 1999, 20-22: „Haec autem sunt allegorica. [...] quaque in duo Testamenta convertit et Sarrae quidem subolem tamquam in libertatem gignentis Novi Testamenti liberos dicit, Agar autem tamquam in servitutem generantis terrenae Hierusalem filios nominavit”, thum. S. Kalinkowski: Orygenes, Homilie o Księdze Liczb, ŹMT 76, Kraków 2016, 114. Por. M. Simonetti, Między dostownościq a alegoria. Przyczynek do historii egzegezy patrystycznej, tłum. T. Skibiński, Kraków 2000, 22-23.

${ }^{5}$ Por. Origenes, Commentarii in Iohannem XXVIII, 22, 190, ed. C. Blanc, SCh 385, Paris 1992 , 154; tenże, In Genesim hom. 13, 3, ed. H. de Lubac - L. Doutreleau, SCh 7bis, Paris 1985, 318-320; tenże, In Exodum hom. 2, 1, ed. M. Borret, SCh 321, Paris 1985, 70. Zob. H. Crouzel, Origène et la „connaissance mystique”, Paris - Bruges 1961, 274: „L'Écriture sert donc de point de départ à la connaissance des mystères”; tenże, Origène et le sens litteral dans ses „Homélies sur l'Hexateuque”, BLE 70 (1969) 245: „La Bible n'a pas en vue l'histoire, mais l'enseignement religieux et spirituel”; Simonetti, Między dostownościq a alegoriq, s. 78; Szram, Duchowy sens liczb, s. 300-303.

${ }^{6}$ Por. Origenes, In Exodum hom. 2, 1, SCh 321, 70: ,in feminis caro et affectus carnis designetur, vir autem rationabilis sensus et intellectualis sit spiritus", thum. S. Kalinkowski: Orygenes, Homilie o Księdze Wyjścia, w: Orygenes, Homilie o Księdze Rodzaju. Homilie o Księdze Wyjścia, ŹMT 64, Kraków 2012, 180.

${ }^{7}$ Por. tamże 2, 2, SCh 321, 76-78, ŹMT 64, 181-182: „Jeśli i ty boisz się Boga, to nie wykonujesz rozkazu króla egipskiego. On nakazuje ci, abyś żył w rozkoszach, kochał obecny wiek, pożądał spraw doczesnych (ut in deliciis vivas, ut diligas praesens saeculum, ut praesentia concupiscas). Jeśli [...] nie wypełniasz tego rozkazu, lecz zachowujesz przy życiu mężczyznę, który jest w tobie (vivificas masculum qui in te est), leczysz swego wewnętrznego człowieka, pielęgnujesz go oraz dobrymi uczynkami i myślami zdobywasz dla niego życie wieczne". 
o mizoginizm. Przykładowo w nawiązaniu do tych samych wydarzeń biblijnych, związanych z nakazem zabijania noworodków płci męskiej, Aleksandryjczyk przedstawił alegoryczną egzegezę położnych egipskich o mówiących imionach Sefora (,wróbel”) i Fua (,wstydliwa”), które - wbrew kojarzeniu się płci żeńskiej z nierozumnością - symbolizują rozumne wykształcenie i wzniosłą naukę duchową (wróbel lata wysoko) i naukę moralną, służącą dobremu wychowaniu (którego cechą jest zachowanie powagi i wstydliwości) ${ }^{8}$.

Celem niniejszego artykułu jest ukazanie pełnego wachlarza sensów duchowych nadawanych żeńskim postaciom biblijnym przez Orygenesa i próba klasyfikacji tych znaczeń. Analiza pod tym kątem całej zachowanej spuścizny egzegetycznej Aleksandryjczyka, obejmującej homilie i komentarze do wielu ksiąg Starego Testamentu (Pięcioksiąg, Księga Jozuego, Księga Sędziów, Pierwsza Księga Samuela, Księga Izajasza, Księga Ezechiela, Księga Jeremiasza, Księga Pieśni nad Pieśniami), pozwoliła wyodrębnić kilka grup duchowych znaczeń wydobytych za pomocą metody alegorycznej, obejmujących nie tylko sferę ludzkich wad, ale także cnót i postaw charakterystycznych dla Kościoła jako Ludu Bożego.

Interesujący nas temat nie był podejmowany we współczesnej literaturze przedmiotu. Kwestia Orygenesowej egzegezy postaci kobiecych nie pojawia się w ważnych opracowaniach dotyczących relacji pisarzy wczesnochrześcijańskich, a zwłaszcza samego Orygenesa, do kobiet ${ }^{9}$. Niniejsze opracowanie ma więc charakter typowo źródłowy.

\section{Kobiety starotestamentalne jako typy Synagogi i Kościoła oraz jako} alegorie walki duchowej. Podstawowe znaczenie typologiczne, jakie Orygenes nadawał starotestamentalnym postaciom kobiecym, miało mocne uzasadnienie biblijne, ponieważ wynikało ze wspomnianej wyżej interpretacji Pawłowej dwóch żon Abrahama - niewolnicy Hagar i wolnej Sary - jako typów wspólnot Starego i Nowego Testamentu (por. Ga 4, 22-24), na którą Orygenes się powoływał ${ }^{10}$. Tę typologię eklezjalną Aleksandryjczyk rozwinął szczegółowo, komentując alegorycznie dwie inne pary biblijnych kobiet zestawione na zasadzie kontrastu. Pierwsza para była związana z postacią Mojżesza. Chodzi

\footnotetext{
${ }^{8}$ Por. tamże 2, 2, SCh 321, 74. Zob nota 13.

${ }^{9}$ Nieliczne nawiązania do aleksandryjskiej egzegezy stworzenia kobiety i grzechu pierwszych rodziców występują w artykule: G. Sfameni Gasparro, La donna nell'esegesi patristica di Gen 1-3, w: La donna nel pensiero cristiano antico, a cura di U. Mattioli, Genova 1992, 17-50. W najważniejszym opracowaniu poświęconym tematyce kobiecej w pismach Orygenesa (D. Gemmiti, La donna in Origene, Napoli - Roma 1996) tematyka egzegetyczna nie jest podejmowana. Brak odniesień do tej kwestii także w skądinąd wartościowym artykule: E. Prinzivalli, Origene, w: Donna e matrimonio alle origini della Chiesa, a cura di E. dal Covolo, Biblioteca di Scienze Religiose 122, Roma 1996, 63-82. Cennym opracowaniem dla zrozumienia źródeł aleksandryjskiego podejścia do egzegezy alegorycznej elementów żeńskich w Biblii jest artykuł: R. Radice, Il femminile come ,, concetto allegorico” in Filone di Alessandria, „Ricerche Storico-Bibliche” 1-2 (1994) 167-177.

${ }^{10}$ Por. Origenes, In Numeros hom. 11, 1, SCh 442, 20-22, ŹMT 76, 114. Zob. nota 4.
} 
o jego siostrę Marię, która wraz z Aaronem robiła bratu wyrzuty (por. Lb 12, 1), i o poślubioną przez patriarchę Etiopkę. Zgodnie z wyjaśnieniem Orygenesa, Maria, która stała się jakby ,płodem poronionym” (por. Lb 12, 10-12), symbolizuje „lud [... który] nie mógł się doskonale ukształtować w Prawie" ${ }^{11}$. Natomiast ślub z Etiopką zapowiada doskonałe poznanie Prawa, ,już nie w symbolach i obrazach, jak dawniej, lecz w samej postaci prawdy", przez lud powołany spośród pogan, symbolizowany przez tę kobietę. Poznanie to jest związane z ukazaniem się światu Syna Bożego, symbolizowanego przez Mojżesza ${ }^{12}$.

Druga para kobiet, którą Orygenes odniósł nie tyle do ludów Starego i Nowego Przymierza, co raczej do ksiag Starego i Nowego Testamentu oraz ich właściwej lektury w Kościele, to wspomniane wyżej dwie położne egipskie, mające z rozkazu faraona dokonywać selekcji noworodków (por. Wj 1, 1522). Podstawą do alegoryzacji stały się mówiące imiona kobiet:

„wydaje mi się, że owe dwie położne stanowią symbol dwóch Testamentów: Sefora, której imię znaczy «Wróbel», może oznaczać Prawo, które «jest duchowe» (por. Rz 7, 14); Fua zaś, czyli «Zaczerwieniona" albo «Wstydliwa», oznacza Ewangelie, które czerwienieją krwią Chrystusa i na całym świecie jaśnieją krwią Jego męki. Dusze zatem, które rodzą się w Kościele, są przez nie jak przez położne otaczane opieką lekarską, bo lektura Pisma przenosi na dusze całą terapię nauki" ${ }^{13}$.

Typy Synagogi wiernej Prawu Mojżeszowemu lub Kościoła pochodzącego z pogan dostrzegł Orygenes również w pojedynczych, nie zestawianych parami postaciach kobiet, charakteryzujących się konkretnymi, pozytywnymi lub negatywnymi cechami charakteru. Synagogę symbolizują kobiety nierozumne, Kościół zaś - kobiety odznaczające się życzliwością i otwartością wobec ludzi znajdujących się w potrzebie. Przykładem pierwszych jest żona Lota, symbolizująca

„ów lud, który po wyjściu z Egiptu i z Morza Czerwonego, [...] (por. Lb 11, 4. 5), obejrzał się za siebie i upadł na pustyni - i stał się przypomnieniem

${ }^{11}$ Por. tamże 7, 3, SCh 415, Paris 1996, 178-180: „Vult in hoc ostendere quod populus ille formatus quidem fuerit in «vulva matris» suae Synagogae, non tamen pervenire potuerit ad perfectum et integrum partum", ŹMT 76, 79.

${ }^{12}$ Por. tamże 7, 2, SCh 415, 172: „Modo enim cum Moyses venit ad nos et coniunctus est huic nostrae Aethiopissae, lex Dei iam non in figuris et imaginibus sicut prius, sed in ipsa specie veritatis agnoscitur; et quae prius in aenigmate designabantur, nunc in specie et veritate complentur", ŹMT 76, 75.

${ }^{13}$ Tenże, In Exodum hom. 2, 2, SCh 321, 74: „Mihi tamen [...] videntur obsetrices istae duae utriusque Testamenti figuram servare, et Sephora, quae passer interpretatur, legi quae spiritalis est, posse conferri; Phua vero, quae rubens vel verecunda est, indicare Evangelia, quae Christi sanguine rubent et per universum mundum passionis eius rutilant cruore. Ab his ergo animae quae nascuntur in Ecclesia, velut obsetricibus medicantur, quia ex Scripturarum lectione cuncta in eas eruditionis medicina confertur", ŹMT 64, 181-182. 
pożądliwości na pustkowiu. Tak więc Prawo straciło i opuściło ów pierwszy lud, podobnie jak Lot stracił i opuścił swą żonę, która się obejrzała"14.

W powyższej interpretacji nie należy dopatrywać się pochopnie i usilnie antyjudaizmu, a jedynie krytyki postawy tych ludzi, nie tylko Żydów, którzy po przyjściu Chrystusa, nie przyjęli Go jako Mesjasza i rozumieli Prawo starotestamentalne nadal w sposób dosłowny ${ }^{15}$. W ten właśnie sposób Orygenes rozumiał symbolikę córek Lota, odnosząc je do Prawa odczytywanego literalnie:

„One, pragnąc rozkrzewić cielesny ród i umocnić siły ziemskiego królestwa licznym potomstwem, upijają ojca [symbolizującego Prawo] i usypiają go, to znaczy zasłaniając i ukrywając jego sens duchowy, wydobywają z niego wyłącznie sens cielesny (tegentes et obumbrantes eius spiritalem sensum, solam ex eo carnis intelligentiam trahunt). [...] Prawo zostaje uśpione po to, aby narodziło się potomstwo, które «nie wejdzie na zgromadzenie Pańskie»"16.

Wśród starotestamentalnych kobiet, będących figurami Kościoła, Orygenes wskazał na córkę faraona, która okazała miłosierdzie wobec porzuconego w bagnie małego Mojżesza:

„Gdy podrósł, zostaje do niej - do Ekklezji (Kościoła) - zaprowadzony i przez nią uznany za syna. Kościół zatem, przychodząc do wód chrztu, przyjmuje również Prawo [symbolizowane przez Mojżesza $\left.{ }^{17}\right]^{118}$.

Inną kobietą symbolizującą Kościół była, według Orygenesa, nierządnica Rachab. Alegoryzację jej postaci Aleksandryjczyk przeprowadził łącząc dwie przesłanki: znaczenie jej imienia oraz grzeszną postawę, związaną z wykonywanym przez nią zajęciem:

„,imię Raab zaś znaczy tyle co «Rozległość» (latitudo). A cóż jest «Rozległością», jeśli nie Kościół Chrystusowy, który został zgromadzony z grzeszników jakby z nierządu?"’19.

${ }^{14}$ Tenże, In Genesim hom. 5, 5, SCh 7bis, 176, thum. S. Kalinkowski: Orygenes, Homilie o Księdze Rodzaju, w: Orygenes, Homilie o Księdze Rodzaju. Homilie o Księdze Wyjścia, ŹMT 64, Kraków 2012, 79-80.

${ }^{15}$ Por. N.R.M. de Lange, Origen and the Jews Bible Exegesis, „Journal of Jewish Studies” 22 (1971) 31-52.

${ }^{16}$ Origenes, In Genesim hom. 5, 5, SCh 7bis, 178, ŹMT 64, 80-81.

${ }^{17}$ Por. tenże, In Iesu Nave hom. 1, 3, ed. A. Jaubert, SCh 71, Paris 1960, 100: „Lex Moyses appellatur".

${ }^{18}$ Tenże, In Exodum hom. 2, 4, SCh 321, 84, ŹMT 64, 185.

${ }^{19}$ Tenże, In Iesu Nave hom. 3, 4, SCh 71, 136, thum. S. Kalinkowski: Orygenes, Homilie o Księdze Jozuego, w: Orygenes, Homilie o Księgach Liczb, Jozuego, Sędziów, PSP 34/2, Warszawa 1986, 19. Por. tamże 7, 5, SCh 71, 206-208, PSP 34/2, 41: „może [...] należy sądzić, że Raab została połączona i zjednoczona aż po dzień dzisiejszy z prawdziwym Izraelem (por. Rdz 19, 37)? [...] wszak my, gałązi dziczki oliwnej, my, którzy zostaliśmy powołani z pogan, my, którzy cudzołożyliśmy czcząc drewno i kamień zamiast prawdziwego Boga, zostaliśmy wszczepieni w ich korzeń aż po dzień dzisiejszy i dzięki wierze znaleźliśmy się wysoko". 
W powyższych przykładach egzegezy typologicznej, zmierzającej do ukazania sensu eklezjalnego, Orygenes kierował się przede wszystkim wspomnianą wskazówką św. Pawła co do sposobu interpretacji dwóch żon Abrahama. Ważnym argumentem był dla niego także żeński rodzaj rzeczownika

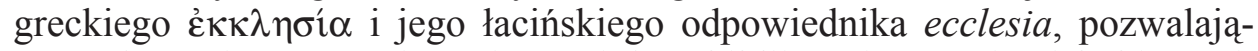
cy na łączenie rzeczywistości Kościoła z biblijnymi postaciami kobiecymi. Aleksandryjczyk w przytoczonych wyjaśnieniach o charakterze typologii nie brał natomiast pod uwagę rozpowszechnionego poglądu o związku zmysłów z osobami rodzaju żeńskiego, a intelektu z osobami rodzaju męskiego. Przekonanie to nie dochodzi do głosu także w będącej kontynuacją interpretacji typologicznej egzegezie duchowo-mistycznej, poszukującej odniesień do walki duchowej, jaką chrześcijanin podejmuje w codziennym życiu. Wprawdzie Orygenes, nadając duchowe znaczenie postaciom niewolnicy Hagar i wolnej Sary, dostrzegł w nich obraz walki ciała przeciw duchowi, która obejmuje zarówno płaszczyznę indywidualną, jak i społeczną, ale cielesność i duchowość związane są w tej alegorii z pojęciami niewoli i wolności, a nie z kobiecością i męskością ${ }^{20}$. Łączenie sfery cielesno-zmysłowej z elementem żeńskim pojawi się natomiast w dokonanych przez Aleksandryjczyka duchowych interpretacjach negatywnie kojarzących się starotestamentalnych postaci kobiecych jako wad moralnych.

2. Kobiety starotestamentalne jako alegorie wad. Ślad wspomnianej praktyki łączenia tego, co cielesne i zmysłowe, z kobiecością, pojawia się w Orygenesowej interpretacji rajskiej Ewy jako alegorii zmysłów odwiedzionych od prostoty, będącej w Chrystusie, przez grzeszną pokusę symbolizowaną przez węża ${ }^{21}$, którego „przyjaciółką” $(\varphi i ́ \lambda \eta)$ - jak stwierdził Orygenes - stała się pierwsza kobieta ${ }^{22}$. Jednakże nawet tak podatna na podobne skojarzenia postać Ewy nie zawsze była rozumiana przez aleksandryjskiego egzegetę w powyższy sposób. Komentując w innym miejscu upadek pierwszych rodziców, zwrócił on uwagę, że symbolami zmysłów ciała są w tym wydarzeniu otwarte na skutek posłuszeństwa wobec rady węża oczy, którymi patrzyli zarówno Ewa, jak i Adam, a nie osobowość czy postawa samej Ewy 23 .

${ }^{20}$ Por. tenże, In Genesim hom. 7, 2, SCh 7bis, 196-200, ŹMT 64, 88-89; tamże 14, 1, SCh 7bis, 336, ŹMT 64, 143.

${ }^{21}$ Por. tenże, In Leviticum hom. 12, 5, ed. M. Borret, SCh 287, Paris 1981, 184, thum. S. Kalinkowski: Orygenes, Homilie o Księdze Kapłańskiej, Kraków 2013, ŹMT 69, 178.

${ }^{22}$ Por. tenże, In Ieremiam hom. 20, 7, ed. P. Husson - P. Nautin, SCh 238, Paris 1977, 282-284:

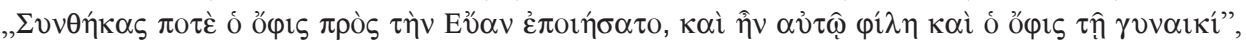
thum. S. Kalinkowski: Orygenes, Homilie o Księdze Jeremiasza, w: Orygenes, Homilie o Księdze Jeremiasza. Komentarz do Lamentacji Jeremiasza. Homilie o Księgach Samuela i Księgach Królewskich, PSP 30, Warszawa 1983, 184: „Wąż zawarł niegdyś umowę z Ewą; był przyjacielem Ewy, a Ewa była jego przyjaciółką".

${ }^{23}$ Por. tenże, In Numeros hom. 17, 3, SCh 442, 278-282, ŹMT 76, 193-195. 
Sytuacja staje się jednoznaczna w przypadku egzegezy duchowej kobiet związanych z osobą Lota. Według Aleksandryjczyka Lot oznacza „rozum i mężnego ducha (rationabilis sensus et animus virilis)", natomiast jego żona jest symbolem „,ciała oddanego pożądliwościom i rozkoszom zmysłowym (caro quae respicit ad vitia [...] et voluptates requirit)” oraz „braku mądrości (insipientia)" ${ }^{24}$. Również córki Lota oznaczają najgroźniejsze wady w życiu duchowym, co Orygenes omówił dość szeroko, przeprowadzając rozbudowaną alegoryzację duchową fragmentu biblijnego opisującego ich występek (por. Rdz 19, 30-36), przeplataną kaznodziejskimi ekshortacjami:

„Gdy unikniesz płomieni wieku, gdy wyrwiesz się z pożaru ciała, a nawet gdy staniesz ponad «małym i niemałym miasteczkiem Segor», które oznacza jakiś pośredni i skromny postęp ${ }^{25}$, gdy wstąpisz na wyżyny wiedzy, jakby na jakieś szczyty górskie, uważaj, żeby nie uknuły spisku przeciw tobie owe dwie córki (duae filiae istae), które cię nie odstępują, lecz idą za tobą, kiedy się wspinasz na górę - mianowicie próżna chwała i jej siostra, pycha (vana gloria et maior soror eius superbia). [...] One zwą się «córkami» dlatego, że nie przychodzą do nas z zewnątrz, lecz wywodzą się z nas samych, jak gdyby z ogółu naszych uczynków (non nobis extrinsecus superveniunt, sed de nobis et de actuum nostrorum velut quadam integritate procedunt). Czuwaj więc w miarę swych sił i bacz, żebyś nie spłodził z nimi synów, bo oni nie wejdą «na zgromadzenie Pańskie» (por. Wj 34, 7), ponieważ z nich się narodzili’”26.

Trudno wyrokować, na ile obecny w powyższej interpretacji wyraźny podział na zmysłowy element żeński i rozumny element męski rzutował na postrzeganie kobiet i rozumienie kobiecości przez Orygenesa. Wspomniana wcześniej dwuznaczna interpretacja grzechu pierwszych rodziców, raz obarczająca winą samą kobietę jako symbol zmysłowości, innym razem przypisująca zarówno odpowiedzialność za grzech, jak i skłonność do cielesnej zmysłowości, obojgu rodzicom, niezależnie od płci, pozwala wnioskować, że stawianie znaku równości między kobiecością i cielesnością, zmysłowością oraz brakiem rozumu, nie było dla Orygenesa oczywiste. Może o tym świadczyć także stosunek ilości negatywnych i pozytywnych interpretacji starotestamentalnych postaci kobiecych $w$ jego zachowanych pismach. Otóż zaprezentowane powyżej nieliczne interpretacje duchowe kobiet jako wad wyczerpują tę listę. Natomiast Orygenesowa alegoryczna egzegeza kobiet jako chrześcijańskich cnót - do której

${ }^{24}$ Por. tenże, In Genesim hom. 5, 2, SCh 7bis, 166-168: „Lot, qui non respexit post se, rationabilis est sensus et animus virilis, uxor autem hic carnis imaginem teneat. Caro est enim quae respicit semper ad vitia, quae, cum animus tendit ad salutem, illa retrorsum respicit et voluptates requirit. [...] Quod autem «fit staticulum salis», insipientiae eius indicium videtur expositum. Sal enim prudentiae loco ponitur, quae ei defuit", ŹMT 64, Kraków 2012, 77.

${ }^{25}$ Najdoskonalszym i najbardziej rozbudowanym przejawem egzegezy duchowej nazw mówiących jest interpretacja nazw miejscowości, w których zatrzymywali się Izraelici podczas wędrówki przez pustynię. Por. tenże, In Numeros hom. 27, SCh 461, Paris 2001, 270-346, ŹMT 76, 293-317.

${ }^{26}$ Tenże, In Genesim hom. 5, 6, SCh 7bis, 180, ŹMT 64, 81. 
prezentacji przejdę obecnie - jest o wiele bardziej rozbudowana. Taka sytuacja wynika zapewne z zachowań samych biblijnych bohaterek poddawanych alegoryzacji, ale też jest przejawem przekonania egzegety, że kobiety zdolne są do postaw heroicznych i również zostały powołane do świętości.

3. Kobiety starotestamentalne jako alegorie cnót. Szereg postaci starotestamentalnych kobiet odegrało pozytywną rolę i już w warstwie znaczenia dosłownego mogły one stanowić przykład zachęcający do zdobywania moralnych cnót. Orygenes usiłował jednak szukać głębszego znaczenia alegorycznego odpowiadającego tym osobom, w czym przychodziła mu z pomoca przede wszystkim metoda interpretacji duchowej mówiących imion owych kobiet, również będących nośnikami pozytywnych treści.

Pierwszy wzór kobiety moralnie dzielnej stanowiła dla Aleksandryjczyka Sara. W daleko idącej pod względem oryginalności skojarzeń interpretacji alegorycznej Orygenes skupił się na duchowym znaczeniu każdego detalu biblijnego przekazu na temat żony Abrahama, przedstawionej przez Niego faraonowi jako siostra:

„[Jej] imię oznacza «przywódcę» (princeps) albo «tego, kto dzierży władzę» (principatum agens), jest symbolem arete, czyli cnoty duchowej (animi virtus). [...]. Otóż jeśli ktoś wziął sobie cnotę za małżonkę, powinien słuchać jej we wszystkim, co mu radzi. [...] Dopóki cnota zwie się żoną, dopóty jest jego wyłączną własnością i z nikim nie może być dzielona. [...] skoro jednak dojdziemy do doskonałości, tak iż jesteśmy zdolni do pouczania innych (por. $2 \mathrm{Tm}$ 2, 2), wówczas nie zamykajmy cnoty niby małżonki w naszym łonie, lecz jako siostrę wiążmy ją z innymi, którzy jej pragną. [...] W takim więc sensie również Abraham mówił, iż Sara jest jego siostrą. Pozwalał zatem, jako człowiek doskonały, aby każdy kto chce, posiadał cnotę"27.

Interpretację związaną z dążeniem do zdobycia cnoty zastosował aleksandryjski egzegeta także w odniesieniu do Sunamitki, która ludowi izraelskiemu, pragnącemu ją wynagrodzić za nakarmienie proroka, odpowiedziała: „Ja mieszkam pośród mojego ludu" (por. $2 \mathrm{Krl} \mathrm{4,} \mathrm{8.} \mathrm{13).} \mathrm{Słowa} \mathrm{te} \mathrm{wyjaśnił} \mathrm{Oryge-}$ nes jako zajmowanie środkowego miejsca, czyli dążenie do nieskłaniania się ku występkom, w czym można dostrzec zainspirowanie się Arystotelesowską ideą „umiarkowania” czy „złotego środka” ( $\mu \varepsilon \sigma o ́ \tau \eta \varsigma)$ jako zasadą kierującą całą antyczną etyką ${ }^{28}$.

${ }^{27}$ Tamże 6, 1, SCh 7bis, 184-186: „Puto ergo Saram, quae interpretatur princeps vel principatum agens, formam tenere $\alpha_{\rho} \varepsilon \tau \uparrow \hat{\eta} \varsigma$, quod est animi virtus. [...] Si quis ergo adscivit sibi in coniugium virtutem, audiat vocem eius in omnibus in quibus consilium dederit ei. [...] Donec enim uxor appellatur virtus, propria est et cum nullo participari potest. [...] cum vero ad perfectum venerimus, ita ud idonei simus et alios docere, tunc iam virtutem non ut uxorem intra gremium concludamus, sed ut sororem etiam aliis volentibus copulemus. [...] Secundum hoc igitur et Abraham Sarram dicebat sororem suam esse. Permittit ergo quasi iam perfectus, ut qui vult habeat virtutem", ŹMT 64, 83.

${ }^{28}$ Por. tenże, In Numeros hom. 3, 2, SCh 415, 80-82, ŹMT 76, 50. Zob. Aristoteles, Etica nico- 
W kontraście do postawy Abrahama wobec cnoty, symbolizowanej przez Sarę, Orygenes przedstawił relację wobec niej innych postaci występujących w biblijnym opowiadaniu, kontynuując skomplikowaną alegorię, której głównym celem jest nie tylko udzielenie odbiorcy homilii wskazówek duchowych dotyczących drogi doskonalenia się w cnotach, ale także ukazanie sposobu, w jaki Bóg przygotowywał świat starożytny na przyjęcie Chrystusa:

„Jeżeli Sara jest symbolem cnoty (virtutis formam tenet Sarra), a Abimelech z czystym sercem chciał posiąść cnotę, to dlaczego powiedziano, iż «Pan nie pozwolił mu jej dotknąć» $(\mathrm{Rdz} 20,6)$ ? Imię «Abimelech» oznacza: «Ojciec mój, król». Wydaje się zatem, iż Abimelech jest tu symbolem uczonych i mędrców świata, którzy zajmują się filozofią i chociaż nie dotarli do pełnej i doskonałej zasady pobożności, to jednak rozumieli, iż Bóg jest Ojcem i Królem wszystkiego [...]. Bóg jednak nie pozwolił im [...] dotknąć [boskiej cnoty], bo łaska ta miała być przekazana poganom nie przez Abrahama, który był wprawdzie wielki, ale był tylko sługą, lecz przez Chrystusa. [...] żonę Abimelecha można określić jako filozofię naturalną, natomiast niewolnice jako różnorakie poglądy dialektyczne różnych szkół filozoficznych (putamus uxorem Abimelech naturalem posse philosophiam dici, ancillas vero eius diversa et varia pro qualitate sectarum commenta dialecticae $)^{29}$. [...] $\mathrm{W}$ rozumieniu alegorycznym faraon, który jest człowiekiem nieczystym i zabójca, w żaden sposób nie mógł posiąść Sary, czyli cnoty, Abimelech natomiast, to znaczy człowiek żyjący w czystości i wedle zasad filozoficznych, mógł ją wprawdzie przyjąć, $[\ldots]$ jednakże «nie nadszedł jeszcze czas» na to (por. J 7, 6). Cnota więc pozostaje u Abrahama, pozostaje przy obrzezaniu, aż nadejdzie czas, aby w Chrystusie Jezusie, Panu naszym, [...] pełna i doskonała cnota przeszła do Kościoła pogan (Manet ergo apud Abraham virtus, manet in circumcisione, donec tempus veniat, ut in Christo Iesu Domino Nostro [...] integra et perfecta virtus ad Ecclesiam gentium transeat). [...] W owym więc czasie dom Abimelecha i jego niewolnice, uzdrowione przez Pana, urodzą synów Kościoła. Jest to bowiem czas, w którym «bezpłodna» rodzi i w którym «więcej synów ma samotna niż ta, która żyje z mężem» (por. Ga 4, 27)"30.

Schemat konstrukcji interpretacji Orygenesa, występujący w przytoczonej egzegezie, jest zbieżny z jego sposobem postępowania znanym z 27 . homilii

machea II 6, 1107a, ed. F. Susemihl - O. Apelt, Lipsiae 1912, 35, thum. D. Gromska: Arystoteles, Etyka nikomachejska, w: Arystoteles, Dzieła wszystkie, t. 5, Warszawa 1996, 113. Por. M. Szram, Cnota pokory w nauczaniu greckich Ojców Kościoła IV wieku, Lublin 2014, 16.

${ }^{29}$ Por. podobny sposób interpretacji: Origenes, In Genesim hom. 11, 2, SCh 7bis, 282-284: „Sane praeter hoc quod ex lege Dei edocemur, si etiam ex his eruditionibus quae extrinsecus videntur esse in saeculo aliquas contingimus - verbi causa, ut est eruditio litterarum vel artis grammaticae, ut est geometrica doctrina vel ratio numerorum vel etiam dialectica disciplina - et haec omnia extrinsecus quaesita ad nostra instituta perducimus atque in assertionem nostrae legis adsciscimus, tunc videbimur vel alienigenas in matrimonium sumpsisse vel etiam concubinas", ŹMT 64, 122-123.

${ }^{30}$ Tamże 6, 2-3, SCh 7bis, 186-192, ŹMT 64, 84-85. 
o Księdze Liczb ${ }^{31}$, opartym na dwóch kryteriach: 1) uznaniu, że tekst biblijny - w tamtym przypadku opisujący wędrówkę Izraelitów przez pustynię, w tym skupiający się na postawie Abrahama i innych postaci wobec jego żony podczas pobytu w Egipcie - dotyczy w swym najgłębszym znaczeniu drogi dochodzenia do świętości i metody zdobywania chrześcijańskich cnót; 2) przyjęciu jako punktu wyjścia znaczenia mówiących nazw własnych, w tamtym przypadku nazw miejscowości, przez które wędrowali Izraelici, w tym - imion głównych bohaterów opisanego zdarzenia, przede wszystkim żony Abrahama, Sary. O ile ta druga przesłanka jest zakotwiczona w tekście biblijnym, chociaż niekoniecznie musi być zgodna ze świadomą intencją autora natchnionego, o tyle pierwsza jest interpretacją wyraźnie odbiegającą od litery tekstu i uzależnioną od koncepcji życia duchowego samego interpretatora, chociaż w pełni zgodną z duchem chrześcijaństwa.

Powyższa egzegeza nie jest przypadkiem odosobnionym w twórczości Orygenesa i ma swoje konsekwencje w odniesieniu do innych żon patriarchów. Można powiedzieć, że postać żony i instytucja małżeństwa oraz relacje między znanymi starotetamentalnymi kobietami i mężczyznami stały się dla Orygenesa uprzywilejowanym motywem starotestamentalnym, służącym do prezentacji cnót istotnych w życiu chrześcijanina oraz sposobu ich nabywania. Pewną

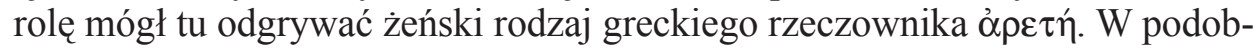
ny sposób, jak Sara, została zinterpretowana przez Aleksandryjczyka żona starego Abrahama - Chettura, rozumiana jako cnota, którą człowiek może zdobyć dopiero wtedy, gdy nie tylko jest mniej podatny na pokusy $\mathrm{z}$ racji wieku, ale już zaawansowany w życiu duchowym, i gdy osiagnął wstępną doskonałośćc ${ }^{32}$ :

„W doskonalszy sposób pojmuje się żonę wówczas, gdy ciało jest już obumarłe (por. Kol 3, 5) [...], większą bowiem zmysły nasze mają zdolność do przyjmowania mądrości wtedy, gdy «nosimy w naszym śmiertelnym ciele konanie Chrystusa» (por. 2Kor 4, 10). Zresztą imię Chettury, które teraz stary Abraham bierze za żonę, tłumaczy się jako Thymiama, to znaczy «Kadzidło» albo «Miła Woń» (incensum vel bonus odor). [...] Jeżeli zatem jest wśród nas ktoś, w kim nie ma wcale woni grzechu, lecz kto pachnie sprawiedliwością, słodyczą miłosierdzia; jeśli ktoś w ustawicznej modlitwie nieustannie składa Panu w ofierze kadzidło [...], to taki człowiek Chetturę bierze za żonę"’33.

\footnotetext{
${ }^{31}$ Por. tenże, In Numeros hom. 27, SCh 461, 270-346, ŹMT 76, 293-317.

${ }^{32}$ Por. tamże 11, 2, SCh 7bis, 282: „Inde ergo est quod nonnullos Patriarcharum simul plures habuisse coniuges, alios defunctis prioribus accepisse alias Scriptura commemorat; ut illud figuraliter indicetur, quod quidam plures simul possunt exercere virtutes, alii non prius quae sequuntur incipere quam priora perduxerint ad perfectum”; ŹMT 64, 122: „niektórzy patriarchowie mieli naraz wiele żon, a inni brali następne małżonki po śmierci poprzednich. Chodziło o to, aby ukazać w sposób symboliczny, iż niektórzy mogą jednocześnie uprawiać wiele cnót, inni zaś mogą osiągnąć kolejne cnoty dopiero po tym, jak poprzednie osiagną doskonałość".

${ }^{33}$ Tamże 11, 2, SCh 7bis, 280: „melius tunc uxor accipitur, quando emortuum corpus est [...]. Maior enim ad sapientiam sensibus nostris capacitas inest, quando «mortificatio Christi circumfertur
} 
Orygenesowska alegoryczna interpretacja starotestamentalnych kobiet jako cnót sprawdzała się szczególnie dobrze w odniesieniu do tekstów, które w literalnym znaczeniu mogły być trudne od przyjęcia z chrześcijańskiego punktu widzenia. Przykładowo Elkana miał dwie żony (por. 1Sm 1, 1-2). Ta poligamia była dla Orygenesa alegorią duchowej zdolności do praktykowania kilku cnót równocześnie, a w tym wypadku konkretnie dwóch symbolizowanych przez mówiące imiona żon Elkany: Fennena - „nawrócenie” (conversio) i Anna - „łaska” (gratia). Aleksandryjczyk zwrócił uwagę, że łaskę powinno się poślubić jako pierwszą, ponieważ to ona umożliwia nawrócenie i przemianę życia. Zauważył jednak, że kolejność płodzenia dzieci przez żony była odwrotna, ponieważ pierwsze owoce w życiu daje nawrócenie i porzucenie złych uczynków, które dopiero umożliwia płodzenie kolejnych duchowych dzieci we współpracy z łaską ${ }^{34}$. Podobnej egzegezie zostały poddane teksty mówiące o poślubieniu cudzoziemek lub nałożnic (por. Pnp 6, 7). Te negatywne w znaczeniu literalnym postacie kobiet $w$ interpretacji alegorycznej Orygenesa nabierają pozytywnego znaczenia nauk świeckich, obejmujących antycz-

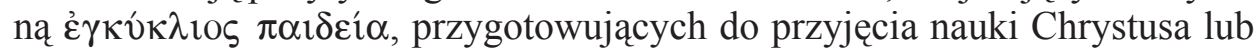
służących do obrony Bożego prawa ${ }^{35}$.

Spośród żon patriarchów, obok żony Abrahama - Sary, najbardziej wszechstronnie poddaną przez Orygenesa alegoryzacji kobietą była żona jego syna Izaaka - Rebeka. Podobnie jak Sara ma ona mówiące imię, wskazujące na cnotę cierpliwości. Izaak spotkał ją przy studni, tak jak Mojżesz Seforę, a Jakub Rachelę, ponieważ studnia (puteus) - jeden z ulubionych obrazów biblijnych, do których odwoływał się w swej egzegezie Orygenes - symbolizuje strumień Bożego Słowa nauczającego mądrości, cierpliwości i wszelkich innych cnót $^{36}$. Związanie się syna Sary z Rebeką było dla Aleksandryjczyka kolejną alegorią procesu doskonalenia się chrześcijanina, oznaczało bowiem przejście od jednej cnoty do drugiej, czyli wzrost na drodze życia

in corpore nostro» mortali. Denique Chettura, quam nunc senex Abraham sortitur in matrimonium, $\theta v \mu^{i} \alpha \mu \alpha$ interpretatur, quod est incensum vel bonus odor. [...] Si quis ergo vestrum est in quo odor peccati iam nullus est, sed odor iustitiae, suavitas misericordiae, si quis sine intermissione orando offert Domino semper incensum [...] hic Chetturam duxit uxorem", ŹMT 64, 121-122.

${ }^{34}$ Por. tenże, In Samuelem hom. 1, 5, ed. P. - M.Th. Nautin, SCh 328, Paris 1986, 110-112: „Fennana interpretatur conversio, Anna autem interpretatur gratia. Unusquisque ergo nostrum, qui vult effici possessio Dei, istas sibi duas iungat uxores et cum ipsis sibi nuptias celebret. Primam sibi iungat, quae nobilior est et generosior, gratiam; haec enim nobis per fidem prima coniungitur [...] secundae vero coniungatur Fennanae, id est conversioni, quia post gratiam credulitatis emendatio fit morum et vitae conversio. Sed cum iste sit ordo nuptiarum, alius ordo procreationis efficitur. Prima namque nobis filios parit Fennana, quia primos fructus de conversione proferimus et prima iustitiae germina de actibus et operibus procreamus. Primum namque iustitiae opus est converti a peccatis, quia, nisi ante convertamur et declinemus a malo, non poterimus de Anna effici patres nec de gratia filios generare", PSP 30, 293-294.

${ }^{35}$ Por. tenże, In Genesim hom. 11, 2, SCh 7bis, 282, ŹMT 64, 122-123. Zob. nota 32.

${ }^{36}$ Por. tenże, In Numeros hom. 12, 1, SCh 442, 74: „quae esset in Scripturis putei vel puteorum virtus exponitur et comparatio fit aquarum, ubi et divini mysterii panduntur arcana", ŹMT 76, 131. 
duchowego ${ }^{37}$. Przy okazji alegoryzacji sceny spotkania Izaaka z Rebeką Orygenes - czuły na każdy szczegół tekstu natchnionego - nie pozostawił bez komentarza stwierdzenia, że Rebeka „zeskakuje z wielbłądów” (por. Rdz 24, 64), czyli odstępuje od błędów i odrzuca nierozumne zmysły ${ }^{38}$. Z jednej strony mamy tu do czynienia z niekonsekwencją egzegety: w jaki sposób cnota cierpliwości, symbolizowana przez Rebekę, miałaby w jakiś sposób być związana $\mathrm{z}$ błądzeniem i nierozumnością? Z drugiej - uwidacznia się w tej interpretacji wpływ obiegowego w tamtych czasach poglądu o związku zmysłowości i nierozumności z płcią żeńską.

Spotkanie z Rebeką było dla Orygenesa nie tylko kolejną alegorią zdobywania cnót. Aleksandryjczyk odczytał w tej scenie sens sięgający głębszych, wręcz mistycznych pokładów życia duchowego. Izaak był w jego przekonaniu typem Chrystusa, który pragnie połączyć się zaślubinami z ludzką duszą, o ile potrafi ona czerpać ze studni wodę prorockiej mowy (potus prophetici sermonis), prowadzącej do poznania Zbawiciela ${ }^{39}$. Ten sposób egzegezy zbliżał się do interpretacji, jaką Orygenes nadał relacji Oblubienicy i Oblubieńca z Pieśni nad Pieśniami.

\section{Oblubienica $z$ Pieśni nad pieśniami jako alegoria Kościoła i duszy} ludzkiej. Omówione dotąd typologiczne i moralno-mistyczne znaczenia przenośne były odnoszone przez Orygenesa do konkretnych, historycznych postaci kobiecych, opisanych na kartach Starego Testamentu. Oddzielnego przedstawienia wymaga egzegeza poetyckiego obrazu Oblubienicy z Księgi Pieśni nad Pieśniami, będącej w zamiarze samego autora biblijnego dziełem symbolicznym, domagającym się wyjaśnienie alegorycznego, co do czego większość pisarzy wczesnochrześcijańskich nie miała wątpliwości ${ }^{40}$. Aleksandryjczyk, zgodnie ze stosowaną przez siebie praktyką egzegetyczna, interpretował postać Oblubienicy na dwóch płaszczyznach: typologicznej (obraz Kościoła jako Oblubienicy Chrystusa) ${ }^{41}$ i moralno-mistycznej (obraz indywidualnej duszy

${ }^{37}$ Por. tenże, In Genesim hom. 10, 5, SCh 7bis, 272: „Qui virtutis filius est Sarrae, nunc coniungitur et sociatur patientiae, quae est Rebecca. Et hoc est transire de virtute in virtutem et ex fide in fidem”, ŹMT 64, 119.

${ }^{38}$ Por. tamże: „Desilit etiam de camelis, id est descendit a vitiis, abicit irrationabiles sensus et coniungitur Isaac".

${ }^{39}$ Por. tamże 10, 2-3, SCh 7bis, 260-262: „Mysteria sunt cuncta quae scripta sunt. Vult et te Christus sibi despondere [...] Ista ergo talis anima, quae agit cuncta patienter, quae tam prompta est et tanta eruditione subnixa quae de profundis haurire scientiae fluenta consuevit, ipsa potest copulari nuptiis Christi. Nisi ergo cotidie venias ad puteos, nisi cotidie haurias aquas, non solum alius potare non poteris, sed ipse quoque sitim verbi Dei patieris", ŹMT 64, 114-115.

${ }^{40}$ Wyjątek stanowiły skrajne tendencje pojawiające się w środowisku antiocheńskim, preferującym egzegezę dosłowną niemal wszystkich ksiąg starotestamentalnych. Por. Simonetti, Między dostownościq a alegoriq, s. 157-179.

${ }^{41}$ Por. Origenes, Canticum canticorum comm. I 1, 5, ed. L. Brésard - H. Crouzel - M. Borret, SCh 375, Paris 1991, 178: „Ecclesia sit desiderans Christo coniungi”, thum. S. Kalinkowski: Ory- 
chrześcijanina jako Oblubienicy Chrystusa) ${ }^{42}$. Oba te znaczenia stanowiły przedłużenie i pogłębienie egzegezy biblijnych postaci kobiecych, nadającej im sens pozytywny.

W znaczeniu typologii eklezjalnej Oblubienica, mówiąca: „Jestem ciemna i piękna, córki Jeruzalem” (Pnp 1,5), symbolizuje Kościół zebrany z pogan, który jest czarny z uwagi na niskie pochodzenie, ale równocześnie piękny dzięki pokucie i wierze w Syna Bożego. Została ona zestawiona przez Aleksandryjczyka z konkretnymi postaciami kobiecymi o ciemnej karnacji, których znaczenie jest podobne: Etiopką, żoną Mojżesza, symbolizującego Prawo duchowe, czyli Słowo Boże przyniesione przez Chrystusa Kościołowi zebranemu z pogan (por. Lb 12, 1-2), i królową Sabą, która przybyła słuchać mądrości Salomona (por. $1 \mathrm{Krl} 10,1-10$ ), będącego również typem Chrystusa. Natomiast córki jerozolimskie gardzące Oblubienicą to przedstawicielki ludu izraelskiego, odnoszące się pogardliwie do nowego ludu Bożego gromadzącego się wokół Chrystusa ${ }^{43}$. Docelowe było jednak - jak zawsze u Orygenesa - znaczenie moralno-mistyczne, stanowiące naturalne przedłużenie typologii:

„Również o każdej duszy, która po popełnieniu wielu grzechów nawraca się do pokuty, można powiedzieć, że jest «czarna» z powodu grzechów, ale «piękna» dzięki pokucie i dzięki «owocowi nawrócenia»"

Jednym $\mathrm{z}$ istotnych warunków procesu duchowego dojrzewania duszy jest zrozumienie Prawa i proroków w sensie duchowym, co mają - zdaniem Orygenesa - symbolizować oczy Oblubienicy porównane przez Oblubieńca do fruwających wysoko gołębic (por. Pnp 1, 15) ${ }^{45}$. Inny rodzaj duchowej wiedzy, konieczny duszy do osiągnięcia doskonałości, to poznanie samej siebie, do czego Oblubieniec zachęca Oblubienicę (por. Pnp 1, 8). Orygenes zwrócił uwagę, że jest to nawiązanie do antycznej zasady przypisywanej tradycyjnie jednemu z siedmiu mędrców greckich ${ }^{46}$. Był jednak przekonany - zgodnie

genes, Komentarz do „Pieśni nad pieśniami”, w: Orygenes, Komentarz do „Pieśni nad pieśniami”. Homilie o „Pieśni nad pieśniami”, Kraków 1994, 38: „Przyjmijmy, że to Kościół pragnie połączyć się z Chrystusem".

${ }^{42}$ Por. tamże I 1, 9, SCh 375, 182: ,introducamus animam, cuius omne studium sit coniungi et consociari Verbo Dei et intra mysteria sapientiae eius ac scientiae veluti sponsi caelestis thalamos intrare”, thum. Kalinkowski, s. 39: „możemy przedstawić duszę, która zabiega usilnie o to, aby się połączyć i zjednoczyć ze Słowem Bożym oraz wejść w tajemnice Jego mądrości i wiedzy jak do komnat niebieskiego Oblubieńca".

${ }^{43}$ Por. tamże II 1, 1-41, SCh 375, 260-284, tłum. Kalinkowski, s. 62-71.

${ }^{44}$ Por. tamże II 1, 56, SCh 375, 292-294: „Potest autem et de unaquaqua anima, quae post peccata plurima convertitur ad paenitentiam, dici quod «nigra» sit pro peccatis, «formosa» autem propter paenitentiam et «fructus paenitentiae»", thum. Kalinkowski, s. 74-75.

${ }^{45}$ Tamże III 1, 4, SCh 376, Paris 1992, 494: „Quod autem oculi eius comparantur columbis, ob hoc profecto, quia Scripturas divinas non iam secundum litteram, sed secundum spiritum intelligat, et adspiciat in iis spiritalia mysteria; columba enim indicium est Spiritus sancti. Spiritali ergo sensu intelligere legem et prophetas, hoc est oculos columbae habere", thum. Kalinkowski, s. 123.

${ }^{46}$ Sentencję „Poznaj samego siebie” ( $\Gamma v \hat{\omega} \theta \imath$ $\left.\sigma \alpha v \tau o ́ v\right)$, wypisaną na świątyni w Delfach, przy- 
$\mathrm{z}$ rozpowszechnioną $\mathrm{w}$ środowisku aleksandryjskim na przełomie II i III w. teorią „kradzieży” mądrości żydowskiej przez Greków - że sentencję tę sformułował żyjący dużo wcześniej król Salomon ${ }^{47}$.

Aby Oblubienica, symbolizująca ludzką duszę, mogła w doskonały sposób zjednoczyć się z Oblubieńcem, musi odrzucić wszelkie nieprawości i przyodziać się w „sprawiedliwość, prawdę, mądrość, skromność i wszystkie cnoty po kolei" ${ }^{48}$. Ponieważ to sam Oblubieniec - Chrystus jest uosobieniem cnoty i stanowi - jak mówił Orygenes - jej substancję (substantia virtutum), zjednoczenie z Nim jest możliwe tylko wtedy, gdy Oblubienica - dusza wydoskonali się w cnotach, i odwrotnie: zdobycie wszelkich cnót jest możliwe dla Oblubienicy - duszy jedynie wówczas, gdy zbliży się i ucałuje Oblubieńca - Chrystusa, który jest źródłem, wzorem i pełnią cnót ${ }^{49}$.

Zgodnie z przekonaniem o wyrazowym natchnieniu Pisma, Orygenes nie pomijał żadnego szczegółu tekstu natchnionego. Wspomnianą przez Oblubienicę matkę (por. Pnp 1, 6) zinterpretował w duchu św. Pawła (por. Hbr 12, 22; Ga 4, 31 - 5, 1) jako alegorię niebiańskiej Jerozolimy, z której ostatecznie pochodzą wszystkie dusze mające jednego Boga za Ojca ${ }^{50}$.

W przypadku Orygenesowej interpretacji postaci Oblubienicy z Pieśni nad pieśniami mamy do czynienia $\mathrm{z}$ apogeum egzegezy o nastawieniu moralno-mistycznym, ponieważ Oblubienica symbolizuje już nie tylko cnoty moralne, ale postawę mistycznej wręcz zażyłości duszy ludzkiej ze Zbawicielem, wyrażoną zawołaniem Oblubienicy: „Jestem ranna z miłości” (Pnp 2, 5) Pod tym względem Aleksandryjczyk wyprzedził o kilkanaście wieków sposób myślenia wielkich mistyków hiszpańskich doby renesansu ${ }^{52}$.

$$
* * *
$$

Przyjęta przez Orygenesa egzegetyczna metoda alegoryzacji całego Starego Testamentu objęła także opisane na jego kartach postacie kobiet. Daleko

pisywano Chilonowi, Solonowi lub Talesowi z Miletu. Por. Aristoteles, Rhetorica II 21, 1395a; Diogenes Laertius, Vitae philosophorum I 40.

${ }^{47}$ Por. Origenes, In Canticum canticorum comm. II 5, 1-9, SCh 375, 354-358, thum. Kalinkowski, s. 91-93.

${ }^{48}$ Por. tamże I 6, 12, SCh 375, 256: ,iustitia dilexit te et veritas et sapientia et pudicitia et singulae quaeque virtutes”, thum. Kalinkowski, s. 60.

${ }^{49}$ Por. tamże: „Nec mireris sane, si dicimus virtutes esse quae diligunt Christum, cum in aliis ipsarum virtutum substantiam Christum soleamus accipere”. Zob. M. Szram, Chrystus jako uosobienie cnót wedtug Orygenesa, w: Droga doskonalenia chrześcijańskiego w epoce patrystycznej. Zagadnienia wybrane, red. F. Drączkowski - J. Pałucki - M. Szram, Lublin 1997, 60-63.

${ }^{50}$ Por. Origenes, In Canticum canticorum comm. II 3, 4, SCh 375, 318, thum. Kalinkowski, s. 80.

${ }^{51}$ Por. tamże III 8, 15, SCh 376, 574: ,,in hoc quasi amatorio dramate sponsa caritatis se dicit vulnera suscepisse. Potest autem similiter fervens anima erga sapientiam Dei dicere quia vulnerata sapientiae ego sum", tłum. S. Kalinkowski, s. 143.

52 Por. J. Daniélou, Origène, Paris 1948, 287-301; E. Stanula, Życie duchowe w ujęciu Orygenesa, w: E. Stanula, Eseje patrystyczne, Warszawa 2014, 87-110. 
idące skojarzenia tych osób z rzeczywistością Kościoła i życiem duchowym chrześcijanina sam autor ocenia jako jedną z możliwych propozycji interpretacyjnych i z właściwą sobie skromnością stwierdza:

„W miarę naszych możliwości ukuliśmy alegoryczne objaśnienie [...]; niczego jednak nie przesądzamy z góry wobec tych, którzy potrafią wyrazić pobożniejszą myśl na ten temat" ${ }^{\prime 3}$.

Konkretne osoby płci żeńskiej, pojawiające się w księgach historycznych Starego Testamentu, są - według Orygenesa - najczęściej typami Synagogi i Kościoła, a zarazem alegoriami ludzkich wad lub cnót. Uosabiają walkę duchową między duchem i ciałem, rozumem i uczuciami. Symbolizują w znaczeniu zbiorowym Synagogę lub Kościół wybrany spośród pogan, a w znaczeniu indywidualnym duszę ludzką w jej relacji do Boga. Aleksandryjczyk odwoływał się do mówiących imion kobiet, tłumacząc je i osadzając w kontekście duchowym. Niejednokrotnie nadawał tej samej postaci kilka różnych przenośnych znaczeń.

Niekiedy Orygenes uznawał, że tekst biblijny nawet bez odwoływania się do metody alegorycznej, już na poziomie interpretacji literalnej jest budujący dla słuchacza, gdy cechy charakteru opisywanych przez autorów biblijnych bohaterek są wyraziste i pouczające. Przykładowo Judyta zwyciężająca Holofernesa w dosłownym znaczeniu stanowi wzór kobiety dzielnej, wspaniałej i szlachetnej ${ }^{54}$. Natomiast Jezabel reprezentuje godną potępienia postawę kobiety okrutnej, prześladującej proroków i hołdującej bałwochwalstwu ${ }^{55}$. Taka literalna egzegeza postaci kobiecych należy jednak w zachowanych homiliach i komentarzach biblijnych Orygenesa do rzadkości.

Mimo przywoływanego na kartach pism Orygenesa przekonania, charakterystycznego dla antycznego świata, głoszącego, że kobieta jest symbolem cielesnych uczuć, a mężczyzna - zdolności intelektualnych, większość interpretacji alegorycznych odnoszących się do starotestamentalnych kobiet

${ }^{53}$ Origenes, In Genesim hom. 5, 5, SCh 7bis, 178-180: „Haec, ut potuimus, secundum allegoricam intelligentiam $[. .$.$] exsculpsimus, nihil praeiudicantes his qui sacratius aliquid de hoc sentire$ potuerint”, ŹMT 64, 81.

${ }^{54}$ Por. Origenes, In Librum Iudicum hom. 9, 1, ed. P. Messie - L. Neyrand - M. Borret, SCh 389, Paris 1993, 210-212: „Quid vero illam magnificam et omnium feminarum nobilissimam memorem Iudith? Quae iam perditis paene rebus non trepidavit sola succurrere seque ac suum caput ad immanissimi Holophernis necem sola subicere et processit ad bellum non in armis neque in equis bellicis aut subsidiis militaribus freta, sed virtute animi et confidentia fidei, consilio autem et audacia hostem peremit; et quam viri perdiderant femina patriae reddidit libertatem", thum. S. Kalinkowski, PSP 34/2, 182; tenże, In Ieremiam hom. 20, 7, SCh 238, 282, PSP 30, 184. W podobny sposób Orygenes chwalił także męstwo Debory. Zob. tenże, In Librum Iudicum hom. 9, 1, SCh 389, 210 : „In superioribus legimus in hoc ipso libello Iudicum de Debborae mulieris triumphis nec femineam mentem infidelis formido turbavit", PSP 34/2, 182.

${ }^{55}$ Por. tenże, In Numeros hom. 20, 1, SCh 461, 22: ,si quis, verbi causa, aut prophetas Dei persequatur, ut illa fecit, aut ad idola aliquos decipiat vel falsis circumscriptionibus perimat innocentes, iste dicitur Iezabel tenere doctrinam”, ŹMT 76, 223. 
wskazuje na personifikacje cnót godnych naśladowania. Wydaje się, że zjawisko to mogło być uwarunkowane bardziej znaczeniem imion tych osób i rolą, jaką przypisali im autorzy biblijni, niż samodzielną decyzją interpretacyjną Orygenesa, niemniej jednak zadaje ono kłam jednoznacznym posądzeniom Aleksandryjczyka czy szerzej - pisarzy wczesnochrześcijańskich w ogóle o zdecydowany mizoginizm.

\section{FEMALE CHARACTERS OF THE OLD TESTAMENT IN THE ALLEGORICAL EXEGESIS OF ORIGEN}

(Summary)

The article systematises the metaphors ascribed by Origen (185-253/254) to the well-known female characters of the Old Testament utilising the method of allegorical exegesis of the text of Scripture. Females appearing on the pages of the historical books of Bible are - according to the Alexandrian - allegories of human virtues or defects. They embody the spiritual warfare between the spirit and the body, between the mind and the feelings. In the collective sense they symbolize the synagogue or the church chosen from the Gentiles, and in the individual sense - the human soul in its relation to God. Origen refers to the telling names of women, translating them and embedding into the spiritual context often giving the several different allegorical meanings to the same biblical person. Despite the often-quoted in his writings beliefs characteristic to the ancient world, proclaiming that the woman is a symbol of bodily feelings and the man - a symbol of the intellectual abilities, majority of allegorical interpretations relating to the Old Testament women indicates a personification of the virtues worthy of imitation. This phenomenon is conditioned with the meaning of the names of those persons and the role attributed to them by the biblical authors, but Origen's interpretations are original and based on his own concept of spiritual life. They deny opinions of misogyny of Origen and the early Christian writers in general.

Translated by Michał Matusiak

Key words: woman, Old Testament, allegorical exegesis, Origen.

Słowa klucze: kobieta, Stary Testament, egzegeza alegoryczna, Orygenes.

\section{BIBLIOGRAFIA}

\section{Źródła}

Origenes, Commentarii in Canticum canticorum, éd. L. Brésard - H. Crouzel - M. Borret, SCh 375-376, Paris 1991-1992, thum. S. Kalinkowski: Orygenes, Komentarz do Pieśni nad pieśniami, w: Orygenes, Komentarz do Pieśni nad pieśniami. Homilie o Pieśni nad pieśniami, Kraków 1994, 7-189. 
Origenes, Commentarii in Iohannem, éd. C. Blanc, XXVIII-XXXII, SCh 385, Paris 1992, tłum. S. Kalinkowski: Orygenes, Komentarz do Ewangelii wedtug św. Jana, ŹMT 27, Kraków 2003.

Origenes, Homiliae in Exodum, éd. M. Borret, SCh 321, Paris 1985, thum. S. Kalinkowski: Orygenes, Homilie o Księdze Wyjścia, w: Orygenes, Homilie o Księdze Rodzaju. Homilie o Księdze Wyjścia, ŹMT 64, Kraków 2012, 169-301.

Origenes, Homiliae in Genesim, éd. H. de Lubac - L. Doutreleau, SCh 7bis, Paris 1985, tłum. S. Kalinkowski: Orygenes, Homilie o Księdze Rodzaju, w: Orygenes, Homilie o Księdze Rodzaju. Homilie o Księdze Wyjścia, ŹMT 64, Kraków 2012, 21-165.

Origenes, Homiliae in Ieremiam, éd. P. Husson - P. Nautin, SCh 232, 238, Paris 19761977, tłum. S. Kalinkowski: Orygenes, Homilie o Księdze Jeremiasza, w: Orygenes, Homilie o Księdze Jeremiasza. Komentarz do Lamentacji Jeremiasza. Homilie o Księgach Samuela i Księgach Królewskich, PSP 30, Warszawa 1983, 23-211.

Origenes, Homiliae in Iesu Nave, éd. A. Jaubert, SCh 71, Paris 1960, tłum. S. Kalinkowski: Orygenes, Homilie o Księdze Jozuego, w: Orygenes, Homilie o Księdze Liczb, Jozuego, Sędziów, PSP 34/2, Warszawa 1986, 3-137.

Origenes, Homiliae in Leviticum, éd. M. Borret, SCh 286-287, Paris 1981, thum. S. Kalinkowski: Orygenes, Homilie o Księdze Kapłańskiej, ŹMT 69, Kraków 2013.

Origenes, Homiliae in Librum Iudicum, éd. P. Messie - L. Neyrand - M. Borret, SCh 389, Paris 1993, thum. S. Kalinkowski: Orygenes, Homilie o Księdze Sędziów, w: Orygenes, Homilie o Księdze Liczb, Jozuego, Sędziów, PSP 34/2, Warszawa 1986, 139-185.

Origenes, Homiliae in Librum primum Regnorum (Samueli I), éd. P. - M.-T. Nautin, SCh 328, Paris 1986; tłum. S. Kalinkowski: Orygenes, Homilie o Księgach Samuela i Księgach Królewskich, w: Orygenes, Homilie o Księdze Jeremiasza. Komentarz do Lamentacji Jeremiasza. Homilie o Księgach Samuela i Księgach Królewskich, PSP 30, Warszawa 1983, 287-319.

Origenes, Homiliae in Numeros, éd. L. Doutreleau, t. 1, SCh 415, Paris 1996; t. 2, SCh 442, Paris 1999; t. 3, SCh 461, Paris 2001; tłum. S. Kalinkowski: Orygenes, Homilie o Księdze Liczb, ŹMT 76, Kraków 2016.

\section{Opracowania}

Crouzel H., Origène et la „,connaissance mystique”, Paris - Bruges 1961.

Crouzel H., Origène et le sens litteral dans ses „Homélies sur l'Hexateuque”, BLE 70 (1969) 241-263.

Crouzel H., Orygenes, tłum. J. Margański, Bydgoszcz 1996.

Daniélou J., Origène, Paris 1948.

Gemmiti D., La donna in Origene, Napoli - Roma 1996.

Hanson R.P.C., Allegory and Event: A Study of the Sources and Significance of Origen's Interpretation of Scripture, London 1959.

HARL M., Origène et les interprétations patristiques grecques de l',obscurité” biblique, VigCh 36 (1982) 334-371.

Lange N.R.M. de, Origen and the Jews Bible Exegesis, „Journal of Jewish Studies” 22 (1971) 31-52.

LuBAC H. de, Histoire et esprit. L'intelligence de l'Écriture d'après Origène, Paris 1950.

LuBAC H. de, ,, Typologie” et ,, allégorisme”, RechSR 34 (1947) 180-226.

Papanikolau A.D., The allegorical exegetical method of Origen, „Theologia” 45 (1974) 347-359.

Prinzivalli E., Origene, w: Donna e matrimonio alle origini della Chiesa, a cura di E. dal Covolo, Biblioteca di Scienze Religiose 122, Roma 1996, 63-82. 
RADICE R., Il femminile come ,, concetto allegorico” in Filone di Alessandria, „Ricerche Storico-Bibliche" 1-2 (1994) 167-177.

Sfameni Gasparro G., La donna nell'esegesi patristica di Gen 1-3, w: La donna nel pensiero cristiano antico, a cura di U. Mattioli, Genova 1992, 17-50.

Simonetti M., Między dosłownościq a alegoriq. Przyczynek do historii egzegezy patrystycznej, tłum. T. Skibiński, Kraków 2000.

Stanula E., Teologiczne zasady interpretacji Pisma świętego, w: Orygenes, O zasadach, thum. S. Kalinkowski, PSP 23, Warszawa 1979, 34-56.

Stanula E., Życie duchowe w ujęciu Orygenesa, w: E. Stanula, Eseje patrystyczne, Warszawa 2014.

Szram M., Duchowy sens liczb w alegorycznej egzegezie aleksandryjskiej (II-Vw.), Lublin 2001.

Szram M., Chrystus jako uosobienie cnót wedtug Orygenesa, w: Droga doskonalenia chrześcijańskiego w epoce patrystycznej. Zagadnienia wybrane, red. F. Drączkowski - J. Pałucki - M. Szram, Lublin 1997, 57-75.

Szram M., Cnota pokory w nauczaniu greckich Ojców Kościoła IV wieku, Lublin 2014.

ZIELIŃsKi J., Alegoreza jako metoda filozoficzno-egzegetyczna w ujęciu Orygenesa, „Acta Universitatis Wratislaviensis" 36 (1999) 295-320.

Zöllig A., Die Inspirationslehre des Origenes. Ein Beitrag zur Dogmengeschichte, Freiburg-im-Breisgau 1902. 